\title{
The Effect of Risks on Banking Safety: Applied Study on Jordanian Traditional Banks (2005-2016)
}

\author{
Mohammad Abdel Mohsen Al-Afeef ${ }^{1} \&$ Atallah Hassan Al-Ta'ani ${ }^{2}$ \\ ${ }^{1}$ Financial and Banking Department, Jerash University, Jordan \\ Correspondence: Mohammad Abdel Mohsen Al-Afeef, Financial and Banking Department, Jerash University, \\ Jordan. E-mail: afeif500@yahoo.com
}

Received: July 4, 2017

Accepted: August 3, 2017

Online Published: August 10, 2017

doi:10.5539/ijef.v9n9p102

URL: https://doi.org/10.5539/ijef.v9n9p102

\begin{abstract}
Banking sector is one of the most important sectors that support the sustainable economic development in Jordan, therefore this study aimed to test the impact of risks; (Liquidity risk, bank credit risk and interest rate risk) on the safety in the banking sector in the Jordanian commercial banks during the period 2005-2016.

The results of the study showed that there is a statistically significant impact for each of liquidity risk and interest rate risk on the safety in the banking sector, and there isn't statistically significant impact for credit risk on the safety in the banking sector during the period of this study, and also find that the explanatory of model was $60.5 \%$, which means that $39.5 \%$ due to other factors.
\end{abstract}

Keywords: bank security, bank credit, traditional Jordanian banks, interest rate changes, liquidity risk

\section{Introduction}

\subsection{Introduce the Problem}

Banking sector has a traditional and important role in pooling savings to finance sustainable development and investment which is the main nerve of economic activity, however, the role of the banking sector in the era of globalization and economic openness has become more important and more serious. In order to keep up with these changes, banks have to play their new role as the most important contact with the outside world, the development and strength of the banking sector have clear indications of the strength and progress of the economy and its ability to attract local and international capital.

Globalization and economic openness are the main challenges facing the banking system in different countries, the rapid growth in investment activities, which need to rise in the banking sector to cope with the developments in all economic and social activities based on the need for finance, directly with a range of risks surrounding the banking business and their negative effects, in the light of the above, the banking sector must have done a duty while maintaining an acceptable level of banking safety by reducing the internal and external risks that may be exposed to it.

The rapid development of the banking sector has been a major development during the past decade in terms of the number of banks, the diversification of banking services and the increase in the volume of deposits and credit facilities due to the expansion and development of investment activities, this has led to an increase in the volume of risk faced by banks, therefore, inquiries are often asked by financial thinkers about how to reach the level of banking safety by identifying the risks that can affect this negatively. In view of the above, the problem of the study is reflected in the following questions:

1) What are the most important banking risks that affect the degree of banking safety in traditional Jordanian banks?

2) What is the effect of liquidity risk on the degree of banking safety in traditional Jordanian banks?

3) What is the impact of credit risk on the degree of banking security in traditional Jordanian banks?

4) What is the impact of interest rate risk on the degree of banking security in traditional Jordanian banks?

\subsection{Importance of the Study}

The importance of this study is reflected in the analytical methodology followed by the two researchers in that it 
dealt with a comprehensive analysis of the most important risks faced by traditional banks in Jordan from the point of view of researchers and the reflection on the level and degree of banking safety and this importance through the following:

1) The importance of the banking sector to the economic sectors, and any imbalances in this sector will affect the rest of the sectors.

2) Banking is exposed to a range of risks due to the expansion of banking operations and the manifestations of globalization.

3) The importance of the degree of banking security to traditional banks in Jordan, where a group of other parties, such as investors and depositors, are concerned about the safety of their investments and deposits to achieve their strategic goals in maximizing wealth.

4) Importance to bank managers by identifying indicators that lead to success and achieving objectives, and avoid negative indicators that predict failure due to some financial and operational risks to which banks are exposed.

\subsection{Objectives of the Study}

In light of the importance of the study, the researchers identified the objectives of the study as follows:

1) Identify the risks to the banking business and determine its sources.

2) Identify the degree of bank safety and its importance to all parties related to conventional banks.

3) Determine the impact of the most important risks to traditional banks in Jordan on the degree of banking safety.

4) Making recommendations for mitigation and hedging of these risks to raise the level of banking safety.

\section{Literature Review}

\subsection{Liquidity}

Liquidity is the ability to provide funds to meet contractual liabilities, which are unsystematic risk facing banking, liquidity is the ability of banks to meet their current liabilities, which can extend up to one accounting period, and the failure to meet the bank's daily obligations is the inability to lend to customers, failure to pay obligations towards the owners of deposits at maturity, non-payment of net liabilities, especially clearing operations with other banks and other current liabilities (Abdel Hamid, 2002; Al Shammari, 2012; Saeed, 2013).

The importance of liquidity in banks, as financial institutions, is that it is the basis of their work, and the failure to manage them leads to bank insolvencies because they reflect the solvency of the bank. Commercial banks are more concerned with liquidity than other specialized banks and other financial institutions, because their ratio of cash liabilities to their total resources is very large, and a large part of their liabilities consist of short-term liabilities (Howells \& Bain, 2000; Qaron, 2013).

Liquidity has three dimensions, namely the time dimension, the speed of the bank to transfer its assets to cash, the second dimension is the risk, the probability of a decline in the value of the assets of the bank, the third dimension is the cost (Cost), which means financial sacrifices And non-financial exposures to liquidity (Howells \& Bain, 2000; Ahmed, 2013).

There is a range of sources where conventional banks can obtain liquidity, such as repaying customers for loans and interest, collecting some financial investments or working on the development and expansion of deposits. Internal sources such as Fed Funds, Such as the Primary Reserve, the Secondary Reserve and other reserves. The main source of liquidity is the strength of the bank and the soundness of its credit position and solvency (Al-Shamma, 1995). The most important advantages of liability management were to give banks flexibility in asset and liability management, the management has been forced to pay attention to the two lists of the financial position as a liquidity management method (Aqel, 1992; Al-Shamma, 1995; Lifta, 2013).

There is a range of bank liquidity measures through a range of financial ratios, such as deposit to asset ratio, which measure the importance of deposits in financing the bank's assets, especially stable deposits that remain in the bank despite economic fluctuations and the ratio of total loans to total assets, The ability of the bank to cover loans through assets and the fact that assets are among the least liquid assets, especially in countries where there is no secondary market for loans or that its market is inactive. This increase is reflected in the expansion of Lending and a decrease in the bank's liquidity. The ratio of total loans to total deposits is a measure of the bank's ability to counter loans through deposits (Institute of Banking Studies, Kuwait, 2012). 
In this study, the researchers used the percentage of total loans to total deposits because the increase in this ratio indicates the increase in the liquidity risk due to the difficulty of liquidating the loans when liquidity is needed and the deposits will not be sufficient to cover the value of the loan, and this percentage is calculated as follows (Al-Shabib, 2015):

$$
\text { Liquidity Risk }=\frac{\text { Total loans }}{\text { Total depositsl }}
$$

\subsection{Interest Rate Risk}

Interest rate risk and volatility are some of the most important systemic risks in banking, because Interest rate accounts for about $90 \%$ of bank revenue. This type of risk is caused by losses which are caused by adverse interest rate fluctuations that involve a significant threat to the Bank's profits and capital (Al-Shabib, 2015).

Banks follow hedging policies for this type of risk, such as managing the interest rate sensitivity gap, which requires maturity analysis and linking interest rate reprising opportunities and their impact on assets, deposits and other loans (Al Said Ali \& Al-Issa, 2004).

Banks can reduce interest rate risk by mitigating fixed-rate lending, entering hedging contracts in the derivative market on interest rate derivatives, and matching bank assets and liabilities in terms of their sensitivity to interest rates such as the use of sources Sensitive funds in the financing of interest rate sensitive assets due to their strong correlation coefficient and the reconciliation between maturities (Al Shabib, 2015).

Interest rate risk is measured by the ratio of Sensitive Assets to Sensitive Liabilities. The most sensitive assets for interest rate fluctuations are short-term securities and floating interest loans. The sensitive liabilities for interest rate changes are demand deposits, savings deposits, short-term deposits and loans received by the Bank. The researchers will measure the risk of interest rate fluctuations through the following ratio (Al-Shabib, 2015):

$$
I . R .=\frac{\text { The sensitive Assets to interest rate change }}{\text { The sensitive Liabilities to interest rate change }}
$$

\subsection{Credit Risk}

Credit is one of the main activities of the Bank, so it is likely to face credit risks, which is one of the most important challenges facing the management of conventional banks. It arises mostly from the possibility that the customer will not be able to repay the loans and their financial obligations or not repay them on time, and this leads to negative repercussions on the bank's income and capital, and also arises because of failure to pay in full on time resulting in financial loss because the bank does not receive interest due and principal of the loan (Hemple, 1999), These risks may be related to the location of the customer or the sector to which he belongs, due to the so-called credit concentration and inaccuracy in determining the creditworthiness of the customer (Al-Shabib, 2015), such risks include items within the budget such as loans, bonds and off-balance sheet items such as letters of credit and Documentary Credits, arising from internal factors related to the bank itself or external factors that affect all aspects of the banking sector and are beyond the control of the administration (Saleh \& Marafi, 2007). Banks are exposed to many risks when making any credit decision, not only the management of bank credit this recognition, but go to find out the reasons for increased risk of such risks (Al-Zubaidi, 2007).

Bank credit risk can be measured through a combination of financial ratios, the most important of which is the ratio of non-performing loans to total loans, and the ratio of bad debts to total loans. The following will be used to measure credit risk (Al-Shabib, 2015):

$$
\text { Credit Risk. }=\frac{\text { Bad debt }}{\text { Total loans }}
$$

\subsection{Banking Safety}

Bank Safety refers to the caution against the risks that banks may face from their operational operations (Kharush et al., 2004), and it reflects the Bank's ability to address the risks that cause losses and decrease Bank profitability and its ability to meet obligations. It is measured by the ability of the Bank to refund deposits to its owners or through risky assets, Which include loans granted, securities, fixed and non-liquid assets, which are difficult to convert to cash quickly and without loss, as well as through the margin of safety in the face of the risks of investment in securities, and the researchers believe that the degree of safety of banking, (Hempel, 1999). The researchers will depend on the measurement of this variable by the following ratio (Kharush et al., 2004, Hempel, 1999):

$$
\text { Banking Safety }(\text { B.S })=\text { Equity } \backslash \text { Risky Assets }
$$


Where the risk assets are total assets minus liquid assets, and the risky assets are loans that are secured or unsecured, as well as investment in securities.

Some previous related studies discussed Bank Safety, like the study of (Kharush et al., 2004), which aimed to determining the factors that affect the degree of banking safety in Jordanian banks using the data issued by the Central Bank and the financial reports of the banks for the period (1992-2002). The researchers reached a number of results, the most important of which is a positive relationship between the degree of banking safety and return On property rights and return on investment and negative relationship of statistical significance between the degree of banking safety and liquidity risk, capital risk and credit risk. The study recommended the need to highlight the importance of banking security to the parties concerned with investment. The study of (Al-Dgaim et al., 2006) dealt with the granting of credit and studies conducted by the Bank on applications for credit facilities at the Industrial Bank and compare it with the credit analysis, this aim is to identify the positive aspects and reinforce them, as well as the deficiencies and make suggestions and recommendations to avoid them, contributes to the rationalization of bank lending operations. (Aduda \& Gitonga, 2011), presented a study aimed to demonstrate the relationship between credit risk management and profitability in Kenyan banks, the study concluded that there is a risk management impact on the profitability of commercial banks in Kenya. A study of (Bakhet \& Eletter, 2012), they trying to develop a model to support the decision to grant credit from non-grants by automating the data on credit seekers to be studied in decision support systems such as the An Artificial Neural Network Model, the study found that this model is promising and very useful in reducing credit risk. (Sohaimi, 2013), the results of the multi-regression study of banks in Malaysia for the years 1997/2012 showed that liquidity risk has an important impact on banks' capital and reserves with non-performing loans to increase liquidity risk, these factors are inversely related to deposits, cash and liquidity. a study for (Al-Ameen et al., 2014), it aimed to know the relation and effect of the determinants of capital adequacy on the adequacy of capital and the degree of banking safety in the Syrian private banks for the period (2007-2011). The results of the study showed the positive relationship between the capital adequacy of the bank and each of the capital risks Return on assets and negative correlation with ROE and credit risk, and that liquidity risk, interest rate risk and IRR are not correlated with capital adequacy in any relationship. On the other hand, the degree of bank security is positively correlated with both capital risk, liquidity risk and interest rate risk and is not correlated with other variables. The study of (Al Ajlouni \& Alrgaibat, 2014), aimed to measuring the impact of banking risks, which represent liquidity risk, credit risk, and interest rate risk on the degree of safety of traditional Jordanian banks. A sample of Jordanian conventional banks was used during the period (2000-2011). The methodology used to analyze the effect of banking risk on a degree of safety in commercial banks is the multiple linear regression. The hypotheses of the study were tested separately for each type of risk, and the results showed a statistically significant relationship between the banking risks and the safety of Jordanian commercial banks. The study recommended that risk management should be continuously monitored by management, with emphasis on credit risk. The study of (Abu Hanifa et al., 2015), aims to demonstrate the impact of credit risk on the profitability of the banking sector in Bangladesh. The study uses data for 18 commercial banks for the period 2003 to 2013. The study found that there is a strong negative impact of NPLGL, LLRGL on all profitability indicators. The analysis also concludes that there is a significant negative impact of CAR on investment returns. The results also showed that the implementation of Basel II on NIM had a positive and negative impact on investment returns. The study of (Almarzoqi \& Alessandro, 2015), analyzed the relationship between banking competition and stability, with a particular focus on the MENA region. It showed that the price of competition has a positive impact on bank liquidity. On the other hand, price competition may have a potential negative impact on the bank's solvency and the solvency of the loan portfolio, and the policies and conditions in each country for market access, regulation and banking control may have a significant impact on the direction and size of the relationship.

Table 1. Summary of the results of related researches

\begin{tabular}{lll}
\hline $\begin{array}{l}\text { Researcher and } \\
\text { Research Year }\end{array}$ & Variable & Result \\
\hline Kharush et al., 2004 & $\begin{array}{l}\text { Degree of banking safety, return On } \\
\text { property rights, return on } \begin{array}{l}\text { A positive relationship between the degree of banking safety and return } \\
\text { Onvestment, liquidity risk, capital }\end{array}\end{array}$ & $\begin{array}{l}\text { of property rights and return on investment and negative relationship } \\
\text { liquidity risk, capital risk and credit risk }\end{array}$ \\
risk, credit risk & $\begin{array}{l}\text { Bank on applications for credit } \\
\text { facilities, credit analysis }\end{array}$ & $\begin{array}{l}\text { Identify the positive aspects and reinforce them, as well as the } \\
\text { deficiencies and make suggestions and recommendations to avoid } \\
\text { them, contributes to the rationalization of bank lending operations }\end{array}$ \\
\hline
\end{tabular}




\begin{tabular}{|c|c|c|}
\hline $\begin{array}{l}\text { Aduda \& Gitonga, } \\
2011\end{array}$ & $\begin{array}{l}\text { credit risk management, } \\
\text { profitability }\end{array}$ & $\begin{array}{l}\text { There is a risk management impact on the profitability of commercial } \\
\text { banks in Kenya }\end{array}$ \\
\hline $\begin{array}{l}\text { Bakhet \& Eletter, } \\
2012\end{array}$ & $\begin{array}{l}\text { Decision to grant credit, An } \\
\text { Artificial Neural Network Model }\end{array}$ & This model is promising and very useful in reducing credit risk \\
\hline Sohaimi, 2013 & $\begin{array}{l}\text { Liquidity, banks' capital, deposits, } \\
\text { cash, reserves, non-performing } \\
\text { loans. }\end{array}$ & $\begin{array}{l}\text { Liquidity risk has an important impact on banks' capital and reserves } \\
\text { with non-performing loans to increase liquidity risk, these factors are } \\
\text { inversely related to deposits, cash and liquidity }\end{array}$ \\
\hline Al-Ameen et al., 2014 & $\begin{array}{l}\text { Bank security, capital adequacy, the } \\
\text { degree of banking safety, ROA, } \\
\text { ROE, credit risk, liquidity risk, } \\
\text { interest rate risk, IRR, , capital risk. }\end{array}$ & $\begin{array}{l}\text { A positive relationship between the capital adequacy of the bank and } \\
\text { each of the capital risks Return on assets and negative correlation with } \\
\text { ROE and credit risk, and that liquidity risk, interest rate risk and IRR } \\
\text { are not correlated with capital adequacy in any relationship. On the } \\
\text { other hand, the degree of bank security is positively correlated with } \\
\text { both capital risk, liquidity risk and interest rate risk and is not } \\
\text { correlated with other variables }\end{array}$ \\
\hline $\begin{array}{l}\text { Al Ajlouni } \\
\text { Alrgaibat, } 2014\end{array}$ & fitability indi & $\begin{array}{l}\text { A strong negative impact of NPLGL, LLRGL on all profitability } \\
\text { indicators. The analysis also concludes that there is a significant } \\
\text { negative impact of CAR on investment returns. The results also } \\
\text { showed that the implementation of Basel II on NIM had a positive and } \\
\text { negative impact on investment returns }\end{array}$ \\
\hline $\begin{array}{l}\text { Almarzoqi } \\
\text { Alessandro, } 2015\end{array}$ & $\begin{array}{l}\text { Banking competition, stability, price } \\
\text { of competition, bank liquidity, } \\
\text { bank's solvency, solvency of the } \\
\text { loan portfolio. }\end{array}$ & $\begin{array}{l}\text { The price of competition has a positive impact on bank liquidity. On } \\
\text { the other hand, price competition may have a potential negative impact } \\
\text { on the bank's solvency and the solvency of the loan portfolio. }\end{array}$ \\
\hline
\end{tabular}

\section{Methodology}

3.1 First: Descriptive Model

\begin{tabular}{|c|c|}
\hline Independent Variable & Dependent Variables \\
\hline Liquidity risk (L.R) & \multirow{3}{*}{$\begin{array}{c}\text { Bank security degree } \\
\text { (S.D) }\end{array}$} \\
\hline Credit risk (C.R) & \\
\hline Interest risk (I.R) & \\
\hline
\end{tabular}

Figure 1. Descriptive model and study variables

Figure 1 shows a descriptive model the independent and dependent variables.

\subsection{Mathematical Model}

The mathematical model was built on the descriptive model, which was adopted by many researchers in clarifying the relation between the variables, as follows (Al Ajlouni \& Alrgaibat, 2014):

$$
B S=\alpha 0+\beta 1 * L R+\beta 2 * C R+\beta 3 * I R+\varepsilon \dot{\varepsilon} i
$$

\section{Whereas:}

BS: Bank Safety

LR: Liquidity Risk

CR: Credit Risk.

IR: Interest Rate Risk

3.3 Hypotheses

According to the importance of the research, problem and questions of the study, the researchers present the following three main hypotheses:

The 1st hypothesis: There is no statistically significant effect of liquidity risk on the degree of banking safety in conventional Jordanian banks. 
The 2nd hypothesis: There is no statistically significant effect of credit risk on the degree of banking safety in traditional Jordanian banks.

The 3rd hypothesis: There is no statistically significant effect of the interest rate risk on the degree of banking safety in the traditional Jordanian banks.

In this study, the researchers relied on the analytical deductive method, based on the financial data of the target banks during the period 2005-2016.

In order to test the effect of independent variables on the dependent variable, the researchers relied on the financial statements published in the annual reports of the banks through the ASE and the Central Bank of Jordan, in addition to the previous literature that examined the subject of the study. The financial analysis was used, by calculating some important financial ratios for this study as well as statistical analysis to analyze data collected using E-Views.

\subsection{Study Sample}

The study population consisted of all traditional Jordanian banks during the period (2005-2016), which are (13) conventional banks, which include all the study sample is the appropriate study society. It is the Jordanian traditional banks whose financial data were available during the period of study after excluding all banks whose financial data were not available during any one year of the study period.

(3) Banks were excluded. So the study was conducted on a sample of 10 banks, the banks that met the requirements, traditional Jordanian banks licensed by the Central Bank of Jordan.

\section{Statistical Analysis}

4.1 Descriptive Statistics

Table 2. The correlation matrix between the variables of the study

\begin{tabular}{lcccc}
\hline Variable & CR & IR & LR & SD \\
\hline CR & 1.000 & -0.015 & 0.025 & -0.078 \\
IR & -0.015 & 1.000 & 0.040 & 0.306 \\
LR & 0.025 & 0.040 & 1.000 & 0.063 \\
SD & -0.078 & 0.306 & 0.063 & 1.000 \\
\hline
\end{tabular}

Table 2 Shows that there is no correlation between the independent variables before analysis by Pearson correlation coefficient. This indicates that the results are not affected by the results of the study model used by the researchers, whether at the level of $(0.01)$ or at the level $(0.05)$. Therefore, the researchers completed the analysis process and tested the hypotheses without having to test the variance inflation factor (VIF).

As shown in Table 2, there is a weak correlation between banking safety and liquidity risk and a positive correlation between banking safety and interest rate risk, and a weak correlation between banking safety and credit risk.

To find out the suitability and acceptability of the model used, the results of the F-test conducted on the study model by the researchers can be found in Table 3:

Table 3. F test

\begin{tabular}{ccccccc}
\hline R-squared & Adjusted R-squared & Sum of Squares R & df & Mean Square & F & Prob. \\
\hline .605 & 0.498 & 40.377 & 3 & .978 & 5.690 & 0.000 \\
\hline
\end{tabular}

The value of F is (5.69) and the mean level of the study model is (0.000) which is less than the acceptable level of 0.05 , as shown in Table (3). This means that the model is acceptable at a significant level (0.01) and (0.05).

\subsection{Hypotheses Test}

To prove or deny the validity of the hypotheses of the study, the researchers conducted the Panel Least Squire test for the study variables. The results of the analysis of the study variables as shown in Table 4: 
Table 4. Results of independent study variables (LR, CR, IR) and dependent variable (SD).

\begin{tabular}{lcccc}
\hline Variable & Coefficient & Std. Error & t-statistic & Prob. \\
\hline (Constant) & 0.281 & 0.385 & -0.729 & 0.467 \\
LR & 1.335 & 0.501 & 2.666 & $0.009^{*}$ \\
CR & 0.251 & 0.074 & 0.338 & 0.736 \\
IR & 0.537 & 0.149 & 3.591 & $0.000^{* * *}$ \\
\hline
\end{tabular}

Note. *With statistical significance at $0.1 ; *$ With statistical significance at $0.1,0.050 .01$.

In view of the results of the analysis in Table (4), the researchers present the results of the hypothesis analysis as follows:

The 1st hypothesis which states: There is no statistically significant effect of the liquidity risk on the degree of banking safety in the traditional Jordanian banks during the period (2005-2016).

Table 4 shows the result of the test of the effect of the first independent variable, the liquidity risk (LR) on the dependent variable, of the banking safety (SD), and the comparison between the $t$ value and the calculated $t$ value of (2.67), And that the significance level is (0.009). Therefore, the hypothesis is rejected.

In other words, there is a statistically significant effect of liquidity risk on the degree of banking safety in the traditional Jordanian banks during the period 2005-2016. The beta coefficient (sensitivity) is 1.34.

The second hypothesis, which states: There is no statistically significant Effect of credit risk on the degree of banking safety in the traditional Jordanian banks during the period (2005-2016).

As shown in Table 4, the result of the 2nd independent variable test is the risk of bank credit (CR) with the dependent variable (SD). It is clear that by comparing tabular t value with calculated value of $(0.338)(0.74)$ which is larger than the tabular and therefore the hypothesis is not rejected.

In other words, there is no statistically significant Effect of credit risk on the degree of banking security in conventional Jordanian banks during the period (2005-2016).

The third hypothesis which states: There is no statistically significant effect of the interest rate risk on the degree of banking safety in the traditional Jordanian banks during the period (2005-2016).

Table 4 also shows the result of the third independent variable test of interest rate risk (IR) with the dependent variable of the banking safety (SD). It is clear that by comparing the $t$ value of the $t$-value with the calculated value of $(3,591)(0.000)$, which is less than the tabular, and therefore the hypothesis is rejected, in other words, there is a statistically significant effect of interest rate risk on the degree of banking safety in traditional Jordanian banks during the period (2005-2016). Beta coefficient (sensitivity) is 0.54.

Table 5. Explanatory power of the model

\begin{tabular}{cccc}
\hline Model & R Square & Adjusted R Square & Std. Error of the Estimate \\
\hline 1 & 0.605 & 0.498 & $0.000^{*}$ \\
\hline
\end{tabular}

Note. *With statistical significance at $0.1,0.050 .01$.

Table 5 shows the explanatory power of the model, where the R-squared is $60.5 \%$, indicating that $60.5 \%$ of the factors influencing bank safety are the factors identified in the study model (liquidity risk, risk Interest rate, credit risk) and that $39.5 \%$ of the factors affecting bank safety are due to other factors outside the model.

\section{Results}

After reviewing the results of the above statistical analysis, the researchers reached the following results:

1) It was found that there is a statistically significant effect of liquidity risk on the degree of banking safety in the traditional Jordanian banks during the period 2005-2016, the result is consistent with the thought of banking and the results of previous studies due to the importance of liquidity in the stability of banking.

2) There is no statistically significant effect of credit risk on the degree of banking safety in the traditional Jordanian banks during the period (2005-2016) this is due to the irregularity of the criteria for the calculation of bad or doubtful debts during the period of study (this was observed when calculating this percentage through the financial reports of the banks subject to the study), this result was consistent with 
the findings of (Al-Ameen et al., 2014).

3) There is a statistically significant effect of the interest rate risk on the degree of banking safety in the traditional Jordanian banks during the period 2005-2016. Consistent with the results of previous studies and the thought of banking because of the sensitivity of banking to fluctuations in interest rates.

4) There is a positive (weak) correlation between bank security and liquidity risk, a positive (medium) correlation with interest rate risk, and a negative correlation with credit risk.

5) The model was able to explain $60.5 \%$ of the changes in the dependent variable (banking safety) through the factors studied in the study (liquidity risk, credit risk and interest rate risk). This is a good ratio, which means that $39.5 \%$ of the changes are attributable to other factors.

\section{Recommendations}

1) Banks should give risk management their most attention to the subject of the degree of banking safety is of great importance to all parties related to conventional banks, and these risks have an impact on the profitability of the bank and even on its continuity and existence.

2) Reducing interest rate risk by mitigating fixed-rate lending, entering hedging contracts in the derivatives market on interest rates, and matching bank assets and liabilities in terms of their sensitivity to interest rates such as the use of sensitive funds in financing interest rate sensitive assets due to their correlation strength.

3) Although there is no statistically significant relationship to credit risk on bank safety in this study (for technical reasons - the instability of methods of measuring bad debts), banks must take this type of risk attention, especially that banks by virtue of their high obligations can not bear the risk of exceeding the value of its assets prominently. The authors recommend that further efforts be made in comprehensive credit analysis and continued monitoring of assets, as well as careful monitoring of general economic conditions to monitor their impact on borrowers, and to anticipate events when negative indicators emerge.

4) Future researchers in this field should look for more risks that affect the degree of banking safety such as (capital adequacy, competition risk, risk of foreign exchange operations, risk of collateral contracts, etc.).

\section{References}

Abdel, H. A. (2002). Comprehensive Banks Operations \& Management (1st ed.). Al Dar Aljameya, Alexandria, Egypt.

Abu Hanifa, N., Pervin, S., Chowdhury, M., \& Banna, H. (2015). The Effect of Credit Risk on the Banking Profitability: A Case on Bangladesh. Journal: Management and Business Research: C Finance 15(3), 40-48. Retrieved from https://globaljournals.org/GJMBR_Volume15/5-The-Effect-of-Credit-Risk.pdf

Aduda, J., \& Gitonga, J. (2011). The Relationship between Credit Risk Management and Profitability among the Commercial Banks in Kenya. Journal: Modern Accounting and Auditing, 9(7), 934-946.

Ahmed, N. (2013). Analytical study of liquidity risk using cash flow statement with an indication of its impact on the adequacy of capital in the banking sector: An applied study in Rafidain Bank. Journal: Baghdad College of Economic Sciences, (36). 300-335. Retrieved from http://iasj.net/iasj?func=fulltext\&aId=82789

Al Ajlouni, M., \& Alrgaibat, G. (2014). Impact of Risk on the Degree of Banking Safety in Traditional Jordanian Banks (2000-2011). Journal: Management and Business Research: C Finance, 14(3), 28-36. Retrieved from https://globaljournals.org/GJMBR_Volume14/5-Impact-of-Risk-on-the-Degree-of-Banking.pdf

Al- Sayed, A., \& Al-Issa, N. (2004). Money and Banks and Financial Markets (1st ed.). Dar Al-Hamed, Amman, Jordan, 2004.

Al- Shammari, S. (2012). Banks Management - Reality and Scientific Applications (1st ed.). Dar Safa, Amman, Jordan.

Al-Ameen, M., Bahlul, M., \& Al-Haris, A. (2014). Determinants of Capital Adequacy and its Impact on Banking Safety - An Empirical Study on Syrian Private Banks. Journal: Tishreen University for Studies and Scientific Research, Economic and Legal Sciences Series, 36(1) 36, 165-187. Retrieved from http://journal.tishreen.edu.sy/index.php/econlaw/article/view/722/692

Al-Dgaim, A., Al- Amin, M., \& Anjro, I. (2006). The Creditory Analysis and its Role in Guiding the Operations of Bank Loaning in the Syrian Industrial Bank. Journal: Studies and Scientific Research - Series of Economic and Legal Sciences, 28(3), 191-210.

Almarzoqi, R., Ben, N. S., \& Alessandro, D. (2015). How Does Bank Competition Affect Solvency, Liquidity 
and Credit Risk? Evidence from the MENA Countries. International Monetary Fund, IMF Working Paper, Middle East and Central Asia. https://doi.org/10.5089/9781513581910.001

Al-Shabib, D. (2015). Banking Operations Management (1st ed.). Dar Al-Maserah, Amman, Jordan.

Al-Shamma, K. (1995). Banks Management (2nd ed.). Baghdad, Iraq: Al-Zahraa Press.

Al-Zubaidi, H. (2007). Bank Credit and Credit Analysis Management (1st ed.). Al-Warraq, Amman, Jordan.

Aqel, M. (1992). Liquidity Management in Jordanian Banks. Lecture at the Association of Banks in Jordan, 22/5/1992.

Bekhet, H., \& Eletter, S. (2012). Credit Risk Management for the Jordanian Commercial Banks: A business Intelligence Approach. Australian Journal of Basic and Applied Sciences, 6(9), 188-195.

Berg, D. H. (2003). Prospective leadership development in colleges and universities in Canada: Perceptions of leaders, educators and students (Unpublished doctoral dissertation, University of Saskatchewan, Saskatoon, Canada).

Hemple, D. (1999). Bank Management: Text and Cases (5th ed.), N.Y.: John Wiley and Sons, Inc.

Howells, P. (2000). Financial Markets and institution (3rd ed.) prentice Hall.

Institute of Banking Studies- Kuwait State. (2012). Liquidity Management at Commercial Bank. Awareness Bulletin, Series 5, 2. Retrieved from http://www.kibs.edu.kw/upload/EDAAT_Sep_2012_401.pdf

Kharush, H., Al-Zubi, K., \& Al- Abadi, M. (2004). Factors Affecting the Degree of Banking Safety in Jordan. Journal: Economics and Management, King Abdulaziz University, 2(18), 59-77. Retrieved from http://www.kau.edu.sa/Files/320/Researches/51705_21840.pdf

Qaron, A. (2013). The extent of the commitment of the Algerian banks to apply capital adequacy in accordance with the recommendations of the Basel Committee (unpublished master dissertation, University of Farhat Abbas, Setif, Algeria). Retrieved from http://www.univ-setif.dz/MMAGISTER/images/facultes/SEG/2013/2013/karouneahmed.pdf

Saeed, A. (2013). Banks and Private Banking Management (1st ed.). Dar al-Yazuri, Baghdad, Iraq.

Saleh, M., \& Marafi, F. (2007). Risk Management and Knowledge Economy - Credit Risk Analysis, Measurement, Management and Reduction. 7th Annual International Scientific Conference, Faculty of Economic and Administrative Sciences, Al-Zaytoonah University, Jordan, pp. 3-12.

Sohaimi, A. (2013). Liquidity Risk and Performance of Banking System in Malaysia. https://doi.org/10.2139/ssrn.2271427

\section{Copyrights}

Copyright for this article is retained by the author(s), with first publication rights granted to the journal.

This is an open-access article distributed under the terms and conditions of the Creative Commons Attribution license (http://creativecommons.org/licenses/by/4.0/). 